\title{
Assessment of Functional and Genetic Diversity of Bacterial Isolates from Uttarakhand Acid Soil
}

\author{
Kiran K. Reddy ${ }^{1,2 *}$, K. Annapurna ${ }^{1}$, Dolamani Amat ${ }^{1,3}$ and L. Vithal Kumar ${ }^{1}$ \\ ${ }^{1}$ Division of Microbiology, Indian Agricultural Research Institute, New Delhi-110 012, India \\ ${ }^{2}$ ICAR-Directorate of Groundnut Research, Junagadh, Gujarat-362 001, India \\ ${ }^{3}$ ICAR-Indian Institute of Soil Science, Bhopal, Madhya Pradesh-462 038, India \\ *Corresponding author
}

\section{A B S T R A C T}

\section{Keywords \\ Plant growth promotion, Bacillus spp., Ochrobactrum spp., Antifungal, HCN and IAA}

Article Info

Accepted:

20 June 2020

Available Online:

10 July 2020
In this study a total of 34 bacterial cultures were isolated from Uttarakhand (Rishikesh) acidic soil ( $\mathrm{pH} 5.6$ ) were screened for plant growth promoting traits. Isolations were carried out on nutrient and kings B agar media in which colony forming unit (CFU) count was $\log _{10} 6.94$ and $\log _{10} 5.04$ respectively. About $17 \%$ and $26 \%$ of the isolates were found to be antagonistic to plant parasitic fungi Fusarium verticilloides and Rhizoctonia bataticola respectively. Indole acetic acid (IAA) production, P-solubilization potential, siderophore and $\mathrm{HCN}$ production was found in $3 \%, 26 \%, 12 \%$ and $6 \%$ of isolates respectively. Genetic diversity was analyzed through $16 \mathrm{~S}$ rDNA sequencing of six selected isolates showing at least two plant growth promoting (PGP) traits. An abundance of Grampositive Firmicutes like Bacillus spp. (50\%) was observed followed by one each strain belonging to $\alpha$-, $\beta$ - and $\gamma$ - proteobacteria. Ochrobactrum spp. LK-8 exhibited different PGP attributes like Siderophore, $\mathrm{HCN}$ production and antifungal activity. Bacillus megaterium LK-23 also showed P-solubilization ability and antifungal activity. Phylogenetic tree illustrated two major clusters each comprising of three strains. In brief, bacterial functional and genetic diversity was affected by site location, climate and edaphic

\section{Introduction}

Poor fertility of acid soils is due to aluminum and manganese toxicity and deficiency of phosphorus, calcium, magnesium, and molybdenum. Al toxicity is a major constraint for crop production on $67 \%$ of the total acid soil area (Eswaran et al., 1997, Kochian et al., 2004). Acid soils limit crop production on 30$40 \%$ of the world's arable land and up to $70 \%$ of the world's potentially arable land (Haug,
1983, Von Uexkull and Mutert, 1995). In India, acid soils cover 90 million ha. They occur at different elevations comprising of various soil textures. About 31 million ha. area show soil acidity problems with $\mathrm{pH}<5.5$ and 59 million ha. have $\mathrm{pH}$ between 5.6 and 6.5 (Sharma and Sarkar, 2005). Strongly acidic soils $(\mathrm{pH}<4.5)$ are majorly present in Arunachal Pradesh, medium acidic soils $(\mathrm{pH}$ 4.5-5.5) are widely distributed in Chhattisgarh, Assam and Kerala and slightly 
acidic soils ( $\mathrm{pH}$ 5.5-6.5) are present in Madhya Pradesh, Orissa, Jharkhand and Uttarakhand.

Plant growth is limited in acid soils majorly due to nutrient imbalances and slow microbial activity which in turn affects bio-geochemical nutrient cycles. Soil acidity also cause hindrance in legume nitrogen fixation by rhizobia, nutrient uptake of sulphur, phosphorus, molybdenum and also affects the rate of organic matter decomposition (Ganeshamurthy et al., 2016). As the soil pH decreases, $\mathrm{Al}^{3+}$ is solubilized and the proportion of phytotoxic $\mathrm{Al}^{3+}$ ions increases in soil solution. In acid soils $\mathrm{P}$ is complexed with $\mathrm{Al}^{3+}$ ions making it unavailable to plants, thus reducing root growth and crop yield (Chen et al., 2012). P deficiency hinders nucleic acid synthesis and various metabolic pathways, as it is associated with primary energy source ATP synthesis (Singh and Satyanarayana 2011).

Plant growth promoting rhizobacteria (PGPR) have been identified in influencing the growth and yield of many plants. The effects of PGPR on plant growth can be mediated by direct or indirect mechanisms. Efficient PGPR strains with multiple activities such as IAA production which modulates root growth and development and mineral phosphate, zinc and potassium solubilization (Tsavkelova et al., 2007), mostly belong to Bacillus spp, Pseudomonas spp. PGPR also affect growth by indirect mechanisms such as suppression of bacterial, fungal and nematode pathogens by production of siderophores (Schmid et al., 2009), lytic enzymes such as lipase, cellulase, protease (Verma et al., 2016), HCN, ammonia, antibiotics, and volatile metabolites etc., or by competition with the pathogen for nutrients or colonization for space. One possible approach is to explore soil microbial diversity for PGPR having PGP activities with sequencing of $16 \mathrm{~S}$ rDNA of isolates, that are well adapted to particular soil environment (Joseph et al., 2007).

The present study aimed at (i) Isolation of bacteria from acidic soil of Uttarakhand (ii) Screening for plant growth promoting (PGP) attributes and (iii) Diversity analysis through 16S rDNA sequencing.

\section{Materials and Methods}

\section{Sample collection}

Soil samples were collected from Rishikesh, Uttarakhand. Ten sub-samples of soil from top $15 \mathrm{~cm}$ were collected and bulked. The samples were brought to the lab and stored at $4^{0} \mathrm{C}$ till further use. Available $\mathrm{N}$ was estimated following protocol of Subbaiah and Asija (1956), available $\mathrm{P}_{2} \mathrm{O}_{5}$ as per Olsen et $a l$., (1954) and available $\mathrm{K}_{2} \mathrm{O}$ as per Hanway and Heidal, (1952).Modified Walkley and Black (1934) protocol was used for estimation of organic carbon in soil. Soil $\mathrm{pH}$ and EC were determined with the help of $\mathrm{ATAGO}^{\circledR}$ $\mathrm{pH}$ and $\mathrm{EC}$ meter.

\section{Isolation of bacteria by serial dilution method}

Two different media - Nutrient agar and King's B were used for isolation. Bacteria were isolated using serial dilution method. $10 \mathrm{~g}$ of soil sample was added to $90 \mathrm{ml}$ of sterile water and shaken for $15 \mathrm{~min}$ on mechanical rotary shaker. Ten-fold dilutions were made and plated on to the two media maintained at $\mathrm{pH}$ 5.5. Plates were incubated at $28 \pm 1^{0} \mathrm{C}$ for 24 hours and colonies were selected based on distinct morphology. Bacterial colonies isolated from Kings B agar and nutrient agar was given LK and $\mathrm{L}$ as prefix for numbering the isolates. The population of bacteria was enumerated using standard plate technique and the results were expressed as CFU per gram of soil. 


\section{Preparation of different nutrient media}

Different nutrient media are prepared according to standard composition, such as Kings $\mathrm{B}$ agar medium (proteose peptone $20 \mathrm{~g}$, glycerol $10 \mathrm{ml}, \mathrm{K}_{2} \mathrm{HPO}_{4} 1.5 \mathrm{~g}, \mathrm{MgSO}_{4} .7 \mathrm{H}_{2} \mathrm{O}$ $1.5 \mathrm{~g}$ and agar $18 \mathrm{~g}$, volume made to 1 lit. with distilled water), Nutrient agar medium (peptone $5 \mathrm{~g}, \mathrm{NaCl} 5 \mathrm{~g}$, beef extract $3 \mathrm{~g}$ and agar $18 \mathrm{~g}$, volume made to 1 lit. with distilled water), Luria Bertini (LB) agar medium (tryptone $10 \mathrm{~g}$, yeast extract $5 \mathrm{~g}, \mathrm{NaCl} 10 \mathrm{~g}$ and Agar $18 \mathrm{~g}$, volume made to 1 lit. with distilled water), $\mathrm{HCN}$ production medium (peptone 20 $\mathrm{g}$, glycerol $10 \mathrm{ml}, \mathrm{K}_{2} \mathrm{HPO}_{4} 1.5 \mathrm{~g}, \mathrm{MgSO}_{4} .7 \mathrm{H}_{2} \mathrm{O}$ $1.5 \mathrm{~g}$, glycine $4.4 \mathrm{~g}$ and agar $18 \mathrm{~g}$, volume made to 1 lit. with distilled water), Potato dextrose agar (PDA) medium (un-peeled potatoes $300 \mathrm{~g}$, dextrose $20 \mathrm{~g}$ and agar $20 \mathrm{~g}$, volume made to 1 lit. with distilled water), Pikovskaya's medium (glucose $10 \mathrm{~g}$, tricalcium phosphate $5 \mathrm{~g}$, ammonium sulphate $0.5 \mathrm{~g}$, sodium chloride $0.2 \mathrm{~g}, \mathrm{MgSO}_{4} \cdot 7 \mathrm{H}_{2} \mathrm{O}$ $0.1 \mathrm{~g}, \quad \mathrm{KCl} 0.2 \mathrm{~g}$, yeast extract $0.5 \mathrm{~g}$, $\mathrm{MnSO}_{4} \& \mathrm{FeSO}_{4}$ in trace amounts and Agar 18 $\mathrm{g}$, volume made to 1 lit. with distilled water), CAS medium (dissolve $60.5 \mathrm{mg}$ of chromeazure $S$ in $50 \mathrm{ml}$ of distilled water and add 10 $\mathrm{ml} \mathrm{Fe}{ }^{2+}$ solution, which is made by adding 1 $\mathrm{ml} \mathrm{FeCl} 2$ in $10 \mathrm{ml} \mathrm{HCl}$. The resultant solution was added to $72.9 \mathrm{mg}$ of HDTMA dissolved in $40 \mathrm{ml}$ of distilled water. This final solution is mixed with 1 lit. of nutrient agar medium). $\mathrm{pH}$ of all the media except Pikovskaya agar is adjusted to 5.5 and autoclaved to get the sterile media.

Screening for plant growth promoting traits to assess functional diversity

All the isolates were screened for the expression of plant growth promoting attributes using specific media. Qualitative IAA production was estimated by following the method of Bric et al., (1991), phosphate solubilization was observed on Pikovaskya's agar plates (Gaur et al., 1990), HCN production was detected by the method of Lorck (1948), siderophore production was estimated on Chrome azurol S-agar medium (CAS) developed by Schwyn and Neilands (1987), and antifungal activity of the isolates was tested following the method given by Mehmood et al., (1999). All the experiments were done in duplicate.

\section{Assessing genetic diversity of acid tolerant bacteria}

\section{Extraction of genomic DNA, 16S rDNA amplification, sequencing and strain identification}

Bacterial isolates possessing at least two PGP properties were selected for genetic diversity studies. Genomic DNA of the selected 34 isolates was isolated using ZR Genomic DNA II isolation kit (Prolab). Amplification of 16S rDNA region was done by using universal primers Forward (5'-AGAGTTTGATCCT GGCTCAG-3') and Reverse (5'- AAGGAG GTGATCCAGCCGCA- $\quad 3$ '). DNA amplification was carried out in Peltier Thermal Cycler PTC 200 (M.J Research). The resulting PCR product ( $3 \mathrm{ul}$ ) was checked by gel electrophoresis at $100 \mathrm{~V}$ for $60 \mathrm{~min}$ on $0.8 \%$ agarose gel. Remaining PCR products were purified using Qiagen Purification Kit as per the manufacturer's instructions, quantified using Nano Drop spectrophotometer and sent to Sequencing Facility at UDSC, New Delhi21 and to Bangalore Genei, Bangalore for sequencing.

\section{Phylogenetic analysis}

Phylogenetic and molecular evolutionary analyses of the sequences of 6 isolates were conducted by using software included in MEGA4. All 6 sequences of 16S rDNA of bacteria were aligned using multiple sequence alignment program CLUSTAL-W. The pair 
wise evolutionary distances matrix was generated as described by Jukes and Cantor (1969) and phylogenetic trees was inferred by the Neighbour joining method. Tree topologies were evaluated by boot strap analysis based on resampling of 500 times of the neighbour joining data set. Sequences were examined and edited using BioEdit Sequence Alignment Editor (http://www.mbio.ncsu.edu/)

BioEdit/bioedit.html) and compared with $16 \mathrm{~S}$ rRNA sequences available by the BLAST search.

\section{Results and Discussion}

\section{Colony forming unit (CFU) counts and soil physio-chemical properties}

Bacterial colony counts of the Uttarakhand acid soil was $8.73 \times 10^{6} \mathrm{CFU} / \mathrm{g}\left(\log _{10} 6.94\right)$ on nutrient agar and $1.12 \times 10^{5} \mathrm{CFU} / \mathrm{g}\left(\log _{10}\right.$ 5.04) on Kings $\mathrm{B}$ agar medium. $\mathrm{pH}_{(1: 2.5)}$ was found to be 5.60 and electric conductivity $\left(\mathrm{EC}_{(1: 2.5)}\right.$ was found to be $0.044 \mathrm{dS} / \mathrm{m}$. Soil texture was sandy loam and the available soil nitrogen content was medium (412 kg/ha), available soil phosphorus was low (10.8 $\mathrm{kg} / \mathrm{ha}$ ), available soil potassium content was high (433 kg/ha) and organic carbon content was very high $(1.7 \%)$. Total 34 isolates were isolated from both the media based on visual variability in colony morphology and color. A total of 22 bacterial colonies were isolated from Kings B agar and 12 bacterial colonies were isolated from Nutrient agar. In the experiment it was revealed to us that bacterial strains isolated from Kings B agar base has more PGP traits compared to strains isolated from nutrient agar.

\section{Bacterial isolates exhibiting different plant growth promoting (PGP) traits}

Out of 34 isolates from Uttarakhand acidic soil, only one isolate was IAA positive (2.9\%). Nine isolates $(26.4 \%)$ showed phosphate solubilization (26.4\%). However, the zone of solubilization was small, indicating them to be weak P-solubilizers. Four isolates (11.7\%) LK-1, LK-6, LK-8 and L-16 showed strong orange halos around the colonies, indicating the production of siderophores (Table 1). Only two isolates LK3, LK-8 were HCN positive, where the filter paper turns to pink color due to reaction of indole compound with Salkowski reagent. Six isolates (17.6\%) LK-8, LK-15, LK-16, LK18, LK-20 and LK-23 and 9 isolates (26.4\%) LK-8, LK-9, LK-11, LK-15, LK-16, LK-18, LK-19 and LK-20 were able to inhibit fungal pathogens Fusarium verticilloides and Rhizoctonia bataticola respectively under in vitro conditions (Fig 1). Inhibition against $F$. verticilloides was found to be strong among the isolates. Six bacterial isolates showing atleast two PGP traits were sequenced, 3 of them belong to Bacillus genera (Gram positive, Phyla: Firmicutes) and other three (Gram negative) were Ochrobactrum spp., Bordotellaspp. and Psuedomonas spp., which belong to $\alpha$-, $\beta$ - and $\gamma$-proteobacteria respectively (Table.1)

The acidity of the soil plays prominent role in the microbial selection process as environmental stress has been shown to impact negatively the bacterial diversity. Soil biological processes are carried out by the microbial component which plays an important role in soil fertility and health, indirectly influencing plant productivity. Majority of PGPR produce phytohormones, exhibit antifungal activity and phosphate solubilization properties. PGPR act as suppressors of plant disease, alleviators of abiotic stress and remediators of toxins from the soil (Timmusk et al., 2014). The role of siderophores and $\mathrm{HCN}$ in the control of diseases has been well documented, and IAA production is an important criterion for determining the promotion of plant growth and development. Pseudomonas putida, 
applied as biofertilizer on mustard (Brassica napus L.) enhanced germination percentage, root and shoot length, chlorophyll content due to its IAA producing trait (Pal et al., 2019). IAA is synthesized by microbes in tryptophan dependent or independent pathways. In our study tryptophan was used to qualitatively estimate the IAA production. Screening for phytohormone IAA producing beneficial microbes is an effective tool to understand the microbial-plant interactions (Govindarajan et al., 2007). PGPR isolate Bacillus sp. 12D6 inoculated in wheat has improved root length, root surface area and number of tips when compared to the control, due to production of IAA (Jochum et al., 2019). IAA produced by Bacteria help in microbe-microbe signaling and is vital for initiating symbiotic relationships with plants, like nodule formation (Spaepen et al., 2007). In our study the isolate LK-17 produced IAA which could further be utilized in the production of biofertilizers.

In a pot study, six isolates, three belonging to Bacillus spp. (AvNB-1, AvSB-2 and AvSB-5) and three belonging to Pseudomonas spp. (AvHP-1, AvSP-1 and AvSP-7) improved Pconcentration in the rhizosphere zone of Aloe vera (Thakur et al., 2017). Many different commercial formulations of phosphate solubilizing microbes (PSM) are already available in the market (Ex: Biophos), these formulations primarily contain Bacillus megaterium, B. polymyxa and Pseudomonas striata (Mehnaz, 2016). In our study Bacillus sp. LK-20, Bacillus Megaterium LK-24 and Pseudomonas sp. LK-1 was found to solubilize insoluble $\mathrm{P}$ compounds, which corroborates our findings. Sequestration of Fe through the production of organic acids or siderophores by microbes (Ahmed and Holmstrom, 2014) control pathogenic organisms by depriving them Fe (Saha et al., 2016). A commercial formulation of $\mathrm{Fe}$ mobilizing bacteria, Acidithiobacillus ferrooxidans developed by AgriLife (India) is already available in market (Mehnaz, 2016). Ochrobactrum anthropi TRS2, isolated from tea rhizosphere solubilized phosphate, produced siderophore and IAA in vitro and also exhibited antifungal activity against six test pathogens Phellinus noxius, Poria hypolaterita, Sphaerostilberepens, Sclerotium rolfsii, Sclerotinia sclerotiorum and Alternaria alternata (Chakraborty et al., 2009). The strain Ochrobactrum sp. $\mathrm{A} 44^{\mathrm{T}}$ interferes with quorum sensing (QS) signal of other plant pathogenic virulent Gram-negative bacteria through inactivation of $N$-acyl homoserine lactones (AHLs) and protect plants against soft rot pathogens (Krzyżanowska et al., 2019). Volatile organic compounds like HCN promote plant growth by suppressing pathogens, but also indirectly increase $\mathrm{P}$ availability by metal chelation (Rijavec and Lapanje, 2016). Our finding was that Ochrobactrum sp. LK-8 produced siderophores, antifungal compounds and $\mathrm{HCN}$, which in turn chelated $\mathrm{Fe}^{2+}$, which is essential for plant growth and also in inhibiting phytopathogens. Our observations and results were in concurrence with above mentioned studies

Beneficial PGPR secrete compounds like lipopeptides, polyketides, antibiotics (Compant et al., 2005) and antifungal metabolites (Prashar et al., 2013). Pathogenspecific commercial biocontrol agents are already available to farmers (Velivelli et al., 2014). In a separate study carried out by Srivastava et al., (2016), in paddy crop, Bacillus amyloliquefaciens (SN13) effectively inhibited Rhizoctonia solani, by modulation of defense responses like phytohormone signaling, persistent maintenance of elicitors, production of secondary metabolites and ROS scavengers. In another investigation carried out by Zebelo et al., (2016) in cotton, Bacillus spp. increased gossypol and jasmonic acid secretion reducing larval feeding 
by Spodoptera exigua. Bacillus sp. LK-15, LK-20 and LK-23 exhibited antifungal activity against Fusraium verticilloides and Rhizoctonia bataticola in our study. Based on FAME (Fatty acid methy ester) profiles of over 1428 rhizoplane bacteria isolated from Tea rhizosphere acidic soil, $43 \%$ of the identified isolates belonged to Bacillus genera
(Cakmakci, 2019). Similarly, in our study also, out of six isolates sequenced, three (50\%) were found to be of Bacillus spp., (Table 2) which indicates their tolerance to soil acidity. In our research, we found that diversity of gram-positive isolates are less in acid soils, where as diversity of gram-ve isolates were found to be far higher.

Table.1 Bacterial isolates tested for different plant growth promoting (PGP) traits classified according to activity level

\begin{tabular}{|c|c|c|c|c|c|c|}
\hline \multirow{2}{*}{ Trait } & \multirow{2}{*}{$\begin{array}{c}\text { Indole } \\
\text { acetic acid } \\
\text { (IAA) } \\
\text { production } \\
(1)^{\$}\end{array}$} & \multirow{2}{*}{$\begin{array}{l}\text { P-solubilization } \\
\text { activity* } \\
\text { (9) }\end{array}$} & \multirow{2}{*}{$\begin{array}{l}\text { Siderophore } \\
\text { Production } \\
\text { (4) }\end{array}$} & \multirow{2}{*}{$\begin{array}{l}\text { HCN } \\
\text { Production } \\
\quad(2)\end{array}$} & \multicolumn{2}{|c|}{ Antifungal Assay } \\
\hline & & & & & $\begin{array}{c}\text { Fusarium } \\
\text { verticilloides } \\
\quad(6)\end{array}$ & $\begin{array}{l}\text { Rhizoctonia } \\
\text { bataticola } \\
\text { (9) }\end{array}$ \\
\hline Low $(+)$ & LK-17 & $\begin{array}{l}\text { LK-1, LK-15, LK-16, } \\
\text { LK-20 LK-22, LK- } \\
\text { 23, L-4, L-6, L-7 }\end{array}$ & Nil & LK-3 & Nil & Nil \\
\hline Moderate (++) & Nil & Nil & L-16 & LK-8 & LK-20 & $\begin{array}{c}\text { LK-8, LK-9, } \\
\text { LK-11, LK- } \\
\text { 18, LK-19, } \\
\text { LK-20 }\end{array}$ \\
\hline $\begin{array}{l}\text { High } \\
(+++)\end{array}$ & Nil & Nil & $\begin{array}{l}\text { LK-1, LK-6, } \\
\text { LK-8 }\end{array}$ & Nil & $\begin{array}{l}\text { LK-8, LK-15, LK- } \\
\text { 16, LK-18, LK-23 }\end{array}$ & $\begin{array}{l}\text { LK-15, LK- } \\
\text { 16, LK-23 }\end{array}$ \\
\hline
\end{tabular}

*Isolates with LK-series are the isolated from Kings B agar. Isolates with L-series are isolated from Nutrient Agar. \$ Figures in parenthesis indicate the number of bacterial strains positive for the trait in question

Table.2 Identified six bacterial isolates (BLAST search) from Uttarakhand acidic soil and their description based on plant growth promoting (PGP) traits

\begin{tabular}{|c|c|c|c|c|c|c|c|}
\hline S.No & $\begin{array}{l}\text { Culture } \\
\text { No.: }\end{array}$ & $\begin{array}{c}\text { Best matched } \\
\text { sps. }\end{array}$ & Phylum & PGP traits & $\begin{array}{l}\text { Gram } \\
\text { reaction }\end{array}$ & Identity & Accession No. \\
\hline 1 & LK-1 & Pseudomonas sp. & $\gamma$ - proteobacteria & P-sol, Sid. & - & $100 \%$ & JX 183139 \\
\hline 2 & LK-8 & $\begin{array}{c}\text { Ochrobactrum } \\
\text { sp. }\end{array}$ & $\alpha$-Proteobacteria & $\begin{array}{l}\text { Sid., HCN, } \\
\text { Anti-fungal }\end{array}$ & - & $100 \%$ & JX183138 \\
\hline 3 & LK-15 & Bacillus sp. & Firmicutes & $\begin{array}{l}\text { P.sol, Anti- } \\
\text { fungal }\end{array}$ & + & $100 \%$ & JX 183140 \\
\hline 4 & LK-16 & $\begin{array}{l}\text { Bordetella } \\
\text { pertussis }\end{array}$ & $\beta$-Proteobacteria & $\begin{array}{l}\text { P.sol, Anti- } \\
\text { fungal }\end{array}$ & - & $99 \%$ & JX 183143 \\
\hline 5 & LK-20 & Bacillus sp. & Firmicutes & $\begin{array}{l}\text { P.sol, Anti- } \\
\text { fungal }\end{array}$ & + & $100 \%$ & JX 149558 \\
\hline 6 & LK-23 & $\begin{array}{c}\text { Bacillus } \\
\text { megaterium }\end{array}$ & Firmicutes & $\begin{array}{l}\text { P.sol, Anti- } \\
\text { fungal }\end{array}$ & + & $100 \%$ & JX 149559 \\
\hline
\end{tabular}


Fig.1 Bacterial isolate Ochrobactrum spp. LK-8 showing PGP traits like siderophore production on CAS agar plates and anti-fungal activity against Rhizoctonia bataticola on PDA plates
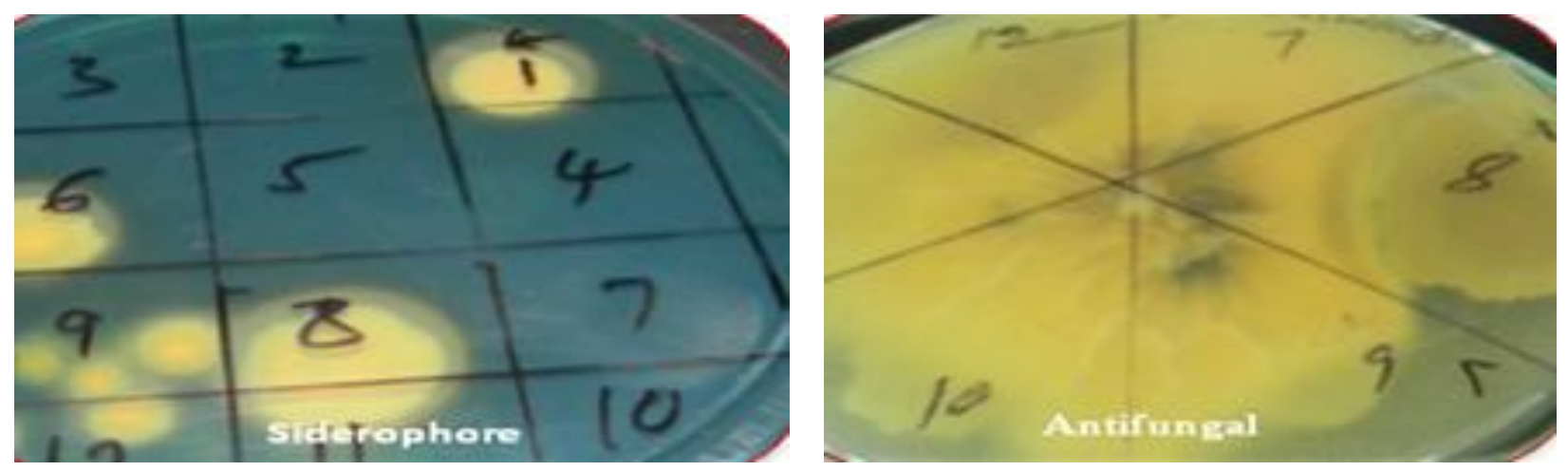

Fig.2 16S rDNA amplification from selected six isolates. M-1Kb Ladder

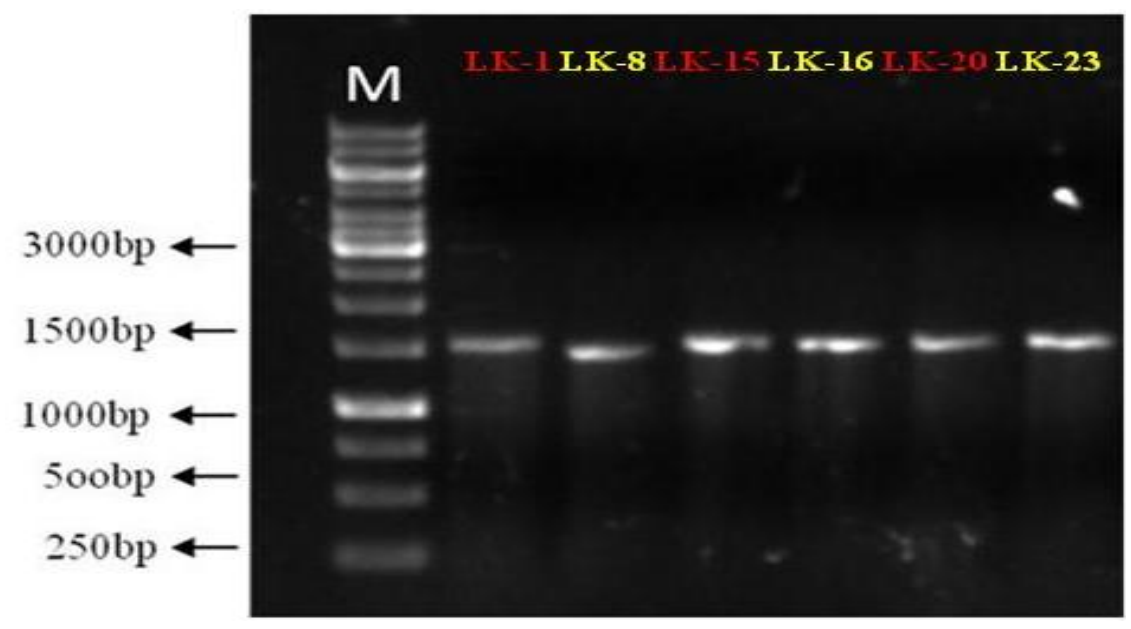

Fig 3: Phylogenetic tree constructed based on 16S rDNA sequences of 6 isolates. Sequence alignment was done using CLUSTAL W software and phylogenetic tree was constructed with NJ algorithm using MEGA4 software. 500 bootstrap replicates were performed

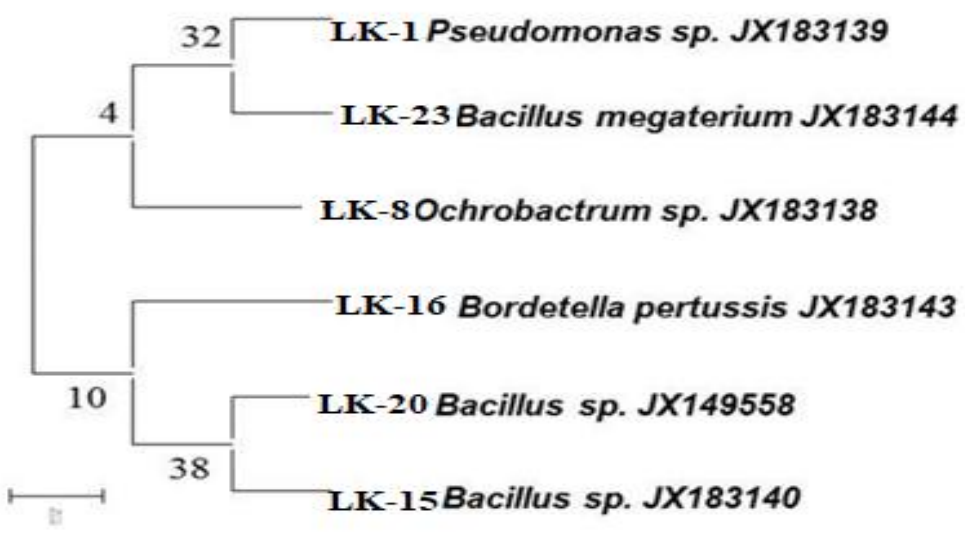


Molecular characterization using 16S rDNA analysis and phylogenetic tree construction

Six isolates from Uttarakhand soil showing at least two plant growth promoting (PGP) traits were selected for molecular characterization. The 16S rDNA of all the 6 isolates were amplified with the 16S rDNA universal primers. A common band of $1.5 \mathrm{~kb}$ was present in all the PCR products (Fig 2). Sequence analysis of these fragments revealed different bacterial genera. There were 4 different bacterial genera found to be distributed in the 6 selected sequences from Uttarakhand acidic soil. Sequence identification revealed majority of them to belong to Bacillus sp. (3), one each belong to Psuedomonas sp., Ochrobactrum sp. and Bordetella pertussis (Table 2). Phylogenetic analyses of the isolates based on the $\mathrm{NJ}$ method with 500 bootstrap sampling resulted into two major clusters (Fig 3).

Bacterial diversity and functions in acidic soils has not been studied extensively. According to O'Donnell et al., (2001) the central problem of the link between bacterial diversity and soil function is to understand the relations between genetic diversity and community structure and between community structure and function. However, genetic and functional structure of this microbial load is an important aspect to best harness them for improving plant productivity in these soils. In our experiment, based on the $16 \mathrm{~S}$ rDNA sequence identification, it was observed that Bacilli sp. was the dominant genus in Uttarakhand acid soil. Being a spore former Bacillus has an edge over other bacterial genera to survive under adverse conditions like low $\mathrm{pH}$. According to Goswami et al., (2018), B. megaterium G18 can survive at $\mathrm{pH}$ 4.5 due to remodeling of arginine and proline metabolic pathways. However, other soil edaphic factors like nutrient status, plant genotype, and site do influence the distribution of particular bacterial genera. Smalla et al., (2001) demonstrated that the plant species, the cultivar, growth stages and soil types influence the relative abundance of bacterial and fungal communities in the rhizosphere. Costa et al., (2006) showed that for most bacterial taxa, the site of isolation seemed to have more pronounced effect on the composition of microbial communities in the rhizosphere. Our study also strengthens this observation. Conclusively soil physicochemical properties and edaphic factors do influence the bacterial diversity of soil to a greater extent.

\section{References}

Ahmed, E., and Holmstrom, S.J. 2014. Siderophores in environmental research: roles and applications. Microbial Biotechnology. 7:196-208 and their major constituents. Indian Journal of Natural Products 13: 10-13.

Bric, J.M., Bostock, R.M., Silverstone, S.E. 1991. Rapid in situ assay for Indole acetic acid production by bacteria immobilized on a nitrocellulose membrane. Applied and Environmental Microbiology 57:535-538.

Cakmakci R. 2019. The variability of the predominant culturable plant growthpromoting rhizobacterial diversity in the acidic tea rhizosphere soils in the eastern black sea region. Alinteri Zirai Bilimler Dergisi. 34:175-181

Chakraborty, U., Chakraborty, B.N., Basnet, M., \& Chakraborty, A.P. 2009. Evaluation of Ochrobactrum anthropi TRS- 2 and its talc based formulation for enhancement of growth of tea plants and management of brown root rot disease. Journal of Applied Microbiology. 107:625-634.

Chen, R.F., Zhang, F.L., Zhang, Q.M., Sun, Q.B., Dong, X.Y., Shen, R.F. 2012. 
Aluminium-phosphorus interactions in plants growing on acid soils: does phosphorus always alleviate aluminium toxicity? The Journal of the Science of Food and Agriculture. 92:995-1000

Compant, S., Duffy, B., Nowak, J., Clément, C., and Barka, E.A. 2005. Use of plant growth-promoting bacteria for biocontrol of plant diseases: principles, mechanisms of action, and future prospects. Applied and Environmental Microbiology. 71:4951-4959

Costa, R., Götz, M., Mrotzek, N., Lottmann, J., Berg, G., Smalla, K. 2006. Effects of site and plant species on rhizosphere community structure as revealed by molecular analysis of different microbial guilds. FEMS Microbiology Ecology. 56:236-249.

Eswaran, H., Reich, P and Beinroth, F. 1997. Global distribution of soils with acidity. In: Plant-Soil Interactions at Low pH. Moniz, A.C. et al. (eds.). Brazilian Soil Science Society. pp. 159-164.

Ganeshamurthy, A.N., Kalaivanan, D., \& Satisha, G.C. 2016. Management of Vegetable Crops in Acid Soils of India. Innovations in Horticultural Sciences. 559-584

Gaur, A.C. 1990. Physiological functions of phosphate solubilizing microorganisms. In: Gaur, A.C. (Ed.), Phosphate Solubilizing Microorganisms as Biofertilizers. Omega Scientific Publishers, New Delhi, pp. 16-72.

Goswami, G., Panda, D., Samanta, R., Boro, R.C., Modi, M.K., Bujarbaruah, K.M., \& Barooah, M. 2018. Bacillus megaterium adapts to acid stress condition through a network of genes: Insight from a genome-wide transcriptome analysis. Scientific reports. 8:1-12.

Govindarajan, M., Kwon, S.W., Weon, H.Y.
2007. Isolation, molecular characterization and growth-promoting activities of endophytic sugarcane diazotroph Klebsiella sp. GR9. World Journal of Microbiology and Biotechnology. 23:997-1006.

Hanway, J. and Heidal, H. S. 1952. Soil analysis methods as used in Iowa State College Soil Testing Laboratory. Iowa State College, Agric. Bull. 57: 1-13.

Haug, A. 1983. Molecular aspects of aluminum toxicity. CRC Critical reviews in plant science. 1:345-373.

Jochum, M., McWilliams, K. M., Borrego, E., Kolomiets, M., Niu, G., Pierson, E., \& Jo, Y. K. 2019. Bioprospecting plant growth-promoting rhizobacteria that mitigate drought stress in grasses. Frontiers in microbiology. 10:2106.

Joseph, B., Patra, R., Lawrence, R. 2007. Characterization of plant growth promoting rhizobacteria associated with chickpea. International journal of plant production. 1: 141-151

Jukes, T.H. and Cantor, C.R. (1969) Evolution of protein molecules. In: Munro HN (ed) Mammalian protein metabolism. Vol 3. Academic Press, New York

Kochian, L.V., Hoekenga, A.O., Piñeros, M.A. 2004. How do plants tolerate acid soils? Mechanisms of aluminum tolerance and phosphorous efficiency. Annual Reviews of Plant Physiology and Plant Molecular Biology. 55:459493

Krzyżanowska, D.M., Maciąg, T., Ossowicki, A., Rajewska, M., Kaczyński, Z., Czerwicka, M. \& Jafra, S. 2019. Ochrobactrum quorumnocens sp. nov., a quorum quenching bacterium from the potato rhizosphere, and comparative genome analysis with related type strains. PLoS One. 14: e0210874. 
Lorck, H. 1948. Production of hydrocyanic acid by bacteria. Plant Physiology. $1: 142-146$

Mehmood, Z., Ahmad, S., Mohammad, F. 1999. Antifungal activity of some essential oils

Mehnaz, S. 2016. "An overview of globally available bioformulations," in Bioformulations: For Sustainable Agriculture, eds N. K. Arora, S. Mehnaz, and R. Balestrini (Berlin: Springer), 267-281.

O'Donnell, A.G., Seasman, M., Macrae, A., Waite, I. and Davies, J.T. 2001. Plants and fertilizers as drivers of change in microbial community structure and function in soils. Plant and Soil. 232: 135-145.

Olsen, S.R., Cole, C.V., Watanabe, F.S., Dean, L. 1954. Estimation of available phosphorus in soil by extraction with sodium carbonate. USDA, Washington, Conc 933.

Pal., Mandal, A.K. and Sengupta, S.C. 2019. Exploitation of IAA Producing PGPR on mustard (Brassica nigra L.) seedling growth under cadmium stress condition in comparison with exogenous IAA application. Plant Science Today. 6:22-30

Prashar, P., Kapoor, N., and Sachdeva, S. 2013. "Biocontrol of plant pathogens using plant growth promoting bacteria," in Sustainable Agriculture Reviews, ed. E. Lichtfouse (Berlin: Springer), 319-360.

Rijavec, T. and Lapanje, A. 2016. Hydrogen cyanide in the rhizosphere: not suppressing plant pathogens, but rather regulating availability of phosphate. Frontiers in Microbiology. 7:1785

Saha, M., Sarkar, S., Sarkar, B., Sharma, B. K., Bhattacharjee, S., and Tribedi, P. 2016. Microbial siderophores and their potential applications: review. Environmental Science and Pollution Research. 23:3984-3999

Schmid, M., Iversen, C., Gontia, I., Stephan, R., Hofmann, A., Hartmann, A., Jha, B., Eberl, L., Riedel, K., Lehner, A. 2009. Evidence for a plant associated natural habitat of Cronobacter spp. Research in Microbiology. 160:608614

Schwyn, B., Neilands, J.B. 1987. Universal chemical assay for the detection and determination of siderophores. Analytical Biochemistry. 160:47-56.

Sharma, P.D. and Sarkar, A.K. 2005. Managing acid soils for enhancing productivity. Indian Council of Agricultural Research NRM Division, Krishi Anusandhan Bhavan-11 New Delhi, p. 22

Singh, B. and Satyanarayana, T. 2011. Microbial phytases in phosphorus acquisition and plant growth promotion. Physiology and Molecular Biology of Plants. 17:93-103

Smalla, K., Wieland, G., Buchner, A., Zock, A., Parzy, J. 2001. Bulk and rhizopshere soil bacterial communities studied by denaturing gel electrophoresis: Plant-dependent enrichment and seasonal shifts revealed. Applied Environmental Microbiology. 67: 4742-4751.

Spaepen, S., Vanderleyden, J., and Remans, R. 2007. Indole-3-acetic acid in microbial and microorganism-plant signaling. FEMS Microbiology Reviews. 31: 425-448

Srivastava, S., Bist, V., Srivastava, S., Singh, P.C., Trivedi, P.K., Asif, M.H. 2016. Unraveling aspects of Bacillus amyloliquefaciens mediated enhanced production of rice under biotic stress of Rhizoctonia solani. Frontiers in Plant Science. 7:587

Subbaiah, B.V., \& Asija, G.L. 1956. A rapid method for estimation of available $\mathrm{N}$ in 
soil. Current Science. 25:259-260.

Thakur, D., Kaur, M., \& Mishra, A. 2017. Isolation and screening of plant growth promoting Bacillus spp. and Pseudomonas spp. and their effect on growth, rhizospheric population and phosphorous concentration of Aloe vera. Journal of Medicinal Plants Studies. 5(1), 187-192.

Timmusk, S., Abd El-Daim, I.A., Copolovici, L., Tanilas, T., Kannaste, A., Behers, L. 2014. Drought-tolerance of wheat improved by rhizosphere bacteria from harsh environments: enhanced biomass production and reduced emissions of stress volatiles. PLoS One .9:e96086.

Tsavkelova, E.A., Cherdyntseva, T.A., Botina, S.G., Netrusov, A.I. 2007. Bacteria associated with orchid roots and microbial production of auxin. Microbiology Research. 162:69-76

Velivelli, S. L., De Vos, P., Kromann, P., Declerck, S., and Prestwich, B.D. 2014. Biological control agents: from field to market, problems, and challenges. Trends in Biotechnology. 32:493-496

Verma, P., Yadav, A.N., Khannam, K.S., Kumar, S., Saxena, A.K., Suman, A.
2016. Molecular diversity and multifarious plant growth promoting attributes of bacilli associated with wheat (Triticum aestivum L.) rhizosphere from six diverse agroecological zones of Journal of Basic Microbiology. 56:44-58

von Uexküll, H.R., Mutert, E. 1995. Global extent, development and economic impact of acid soils. In: Date RA, Grundon NJ, Raymet GE, Probert ME (eds) Plant-soil interactions at low $\mathrm{pH}$ : principles and management. Kluwer Academic Publishers, Dordrecht, pp 519

Walkley, A. and Black. I.A. 1934. An examination of Degtjareff method for determining soil organic matter and a proposed modification of the chromic acid titration method. Soil Science. 37:29-37.

Zebelo, S., Song, Y., Kloepper, J. W., and Fadamiro, H. 2016. Rhizobacteria activates (+)-delta-cadinene synthase genes and induces systemic resistance in cotton against beet armyworm (Spodoptera exigua). Plant, Cell \& Environment. 39:935-943

\section{How to cite this article:}

Kiran K. Reddy, K. Annapurna, Dolamani Amat and Vithal Kumar, L. 2020. Assessment of Functional and Genetic Diversity of Bacterial Isolates from Uttarakhand Acid Soil. Int.J.Curr.Microbiol.App.Sci. 9(07): 2241-2251. doi: https://doi.org/10.20546/ijcmas.2020.907.261 